\title{
Tau, APP, NCT and BACE1 in lymphocytes through cognitively normal ageing and neuropathology
}

\author{
MARISOL HERRERA-RIVERO ${ }^{1}$, ABRAHAM SOTO-CID ${ }^{2}$, \\ MARÍA E. HERNÁNDEZ ${ }^{3}$ and GONZALO E. ARANDA-ABREU ${ }^{3}$ \\ ${ }^{1}$ Doctorado en Ciencias Biomédicas, Centro de Investigaciones Biomédicas, Universidad Veracruzana, \\ Av. Luis Castelazo Ayala, s/n, Carr. Xalapa-Veracruz, Col. Industrial Animas, 91190, Xalapa, Veracruz, Mexico \\ ${ }^{2}$ Clínica 11, Instituto Mexicano del Seguro Social, Facultad de Química Farmacéutica Biológica, Universidad Veracruzana, \\ Av. Luis Castelazo Ayala, s/n, Carr. Xalapa-Veracruz, Col. Industrial Animas, 91190, Xalapa, Veracruz, Mexico \\ ${ }^{3}$ Centro de Investigaciones Cerebrales, Universidad Veracruzana, Cuerpo Académico de Neuroquímica, \\ Av. Luis Castelazo Ayala, s/n, Carr. Xalapa-Veracruz, Col. Industrial Animas, 91190, Xalapa, Veracruz, Mexico \\ Manuscript received on January 9, 2013; accepted for publication on May 17, 2013
}

\begin{abstract}
Although Alzheimer's disease is a brain disorder, a number of peripheral alterations have been found in these patients; however, little is known about how the key genes involved in the pathophysiology express in peripheral cells such as lymphocytes during normal compared to neuropathological ageing. We analysed the expression of tau, of the amyloid precursor protein, of nicastrin and of the $\beta$-site APP cleaving enzyme genes by RT-PCR in lymphocytes from a small group of late-onset Alzheimer's disease patients, from aged patients suffering from neuropsychological conditions different from Alzheimer's and from cognitively healthy subjects divided in four groups by age. We also investigated correlations between gene expression and levels of blood pressure, glucose, total cholesterol and triglycerides as risk factors for Alzheimer's. Results show no tau expression in lymphocytes, a lack of detection of nicastrin expression in Alzheimer's patients and correlations between the medical conditions studied and gene expression in lymphocytes. We believe nicastrin gene expression in lymphocytes should be considered of interest for further analyses in a wider population to investigate whether it might represent a potential biomarker to differentiate Alzheimer's from other neuropsychological disorders.
\end{abstract}

Key words: Alzheimer's disease, APP, BACE1, nicastrin, normal ageing, risk factors.

\section{INTRODUCTION}

The prevalence of dementia above the age of 65 is estimated in around 5\%, gradually increasing up to $20 \%$ in individuals over 85 years of age (Jorm 1990). Although there are more than 60 disorders associated with dementia, Alzheimer's disease (AD) is the most common representing $50-60 \%$ of all dementia cases (de Leon et al. 2007). The most prominent characteristic of $\mathrm{AD}$ is a slowly progressive cognitive

Correspondence to: Gonzalo Emiliano Aranda-Abreu

E-mail: garanda@uv.mx decline due to neuronal damage and loss resulting from amyloid plaque and neurofibrillary tangle development in the brain of these patients. Amyloid plaques are now long known to be mainly constituted of $\beta$-amyloid peptides ( $A \beta 40, A \beta 42)$ generating from the amyloidogenic processing of the amyloid precursor protein (APP), which involves the $\beta$ - and $\gamma$-secretase activities (Selkoe 2001). Nevertheless, pathologic alterations in the brain of Alzheimer's patients are the result of several cellular processes aside of APP and $\mathrm{A} \beta$ metabolism; the hyperphosphorylation of protein 
tau, oxidative stress, mitochondrial dysfunction, alterations in molecular transport, neuroinflammation and lipid dysregulation, amongst others, are also involved in the pathophysiology of AD (Uemura et al. 2004, Tuppo and Arias 2005, Jiménez-Jiménez et al. 2006, Suzuki et al. 2006, Ballatore et al. 2007, Di Paolo and Kim 2011).

The underlying pathological events in AD are the amyloid and tau pathologies with the formation of plaques and tangles. Main roles in $\mathrm{A} \beta$ generation are played by APP, the only protein containing the $\mathrm{A} \beta$ sequence; and the $\beta$ - and $\gamma$ - secretases, which cleave APP to release A $\beta$ peptides (Vassar and Kandalepas 2011). The $\gamma$-secretase is a complex formed by at least four different membrane proteins to constitute an active enzyme: presenilin 1 or 2 (PS1 or PS2), anterior pharynx defective (APH-1), nicastrin (NCT) and presenilin enhancer (PEN-2); $\mathrm{NCT}$ is the largest component of the complex and plays a critical role in the $\gamma$-secretase activity (Yang et al. 2009).

Although $\mathrm{AD}$ is a brain disorder, evidence shows there is a peripheral response to changes occurring in the AD brain; furthermore, the role of inflammation in $\mathrm{AD}$ has been proven and the induction of alterations in the components of the immune system with it. The pathological processes occurring in the $\mathrm{AD}$ brain thus could cause alterations in the periphery as well and possibly some might not be originated solely by central nervous system (CNS) signalling. A series of alterations have been found in blood plasma and cells in AD (Irizarry 2004, Ray et al. 2007, Britshgi and Wyss-Coray 2007). Lymphocytes have shown a variety of abnormalities (Kálmán et al. 2005) and even some similarities with neurons in $\mathrm{AD}$, reason why these cells have been proposed to represent useful tools to study and detect the disease (Gladkevich et al. 2004).

The main risk factor to develop $\mathrm{AD}$ is age; nevertheless, a diversity of factors has been proposed to increase the risk for this disease, including a growing list of genes as well as medical and lifestyle conditions. As neither of these risk factors is sufficient to trigger the pathogenesis of $\mathrm{AD}$, it is reasonable to believe that a combination of a number of them determines whether or not an individual will suffer from the disease, as well as the age of onset. A wide variety of risk factors for $\mathrm{AD}$ have been investigated; although some results remain controversial, several studies show a relation between medical conditions such as hypertension, type 2 diabetes mellitus and high cholesterol and triglycerides blood levels, and the risk to develop late-onset AD (Irizarry 2004, Lane and Farlow 2005, Razay et al. 2007, Cheng et al. 2011).

We analyzed the expression of tau, APP, NCT and the $\beta$-site APP cleaving enzyme (BACE1) in lymphocytes to investigate how these critical molecules for plaque and tangle formation are expressed during cognitively normal and pathological ageing in such peripheral cells. Furthermore, we aimed to investigate for a relation between the expression of these molecules and those we believe represent major risk factors for $\mathrm{AD}$ in the general population.

\section{MATERIALS AND METHODS}

\section{Study Population AND SAMPLE COLLECTION}

All 72 individuals are from Latin origin living in Mexico. All patients had previously been clinically diagnosed in the private practice with possible or probable late-onset $\mathrm{AD}(\mathrm{n}=12)$ and some of the common brain disorders in the elderly, namely vascular dementia (VaD, $\mathrm{n}=1)$, Parkinson's disease (PD, $n=3)$, schizophrenia $(n=1)$, psychotic disorder $(\mathrm{n}=2)$, mild cognitive impairment (MCI, $\mathrm{n}=2$ ), cognitive impairment due to cerebrovascular event (CVE, $n=2$ ) and traumatic brain injury (TBI, n=1). All healthy subjects volunteered and patients were recruited from participants in a different study. Peripheral blood samples were collected by venous puncture after informed consent of all 
healthy subjects and patients' family members. Blood pressure was measured with a wrist digital monitor. All samples were collected after a 12-hour fast and in absence of any known infectious and/or inflammatory conditions. Samples were classified into six experimental groups according to Table I.

TABLE 1

Sample classification and inclusion criteria.

\begin{tabular}{|c|c|c|c|}
\hline Group & $\mathrm{n}$ & Mean age & Inclusion criteria \\
\hline I & 12 & $30 \pm 1$ & Cognitively healthy: no memory \\
\hline II & 12 & $44 \pm 1$ & and/or spatial-temporal problems \\
\hline III & 12 & $58 \pm 1$ & No previous CVE or TBI \\
\hline IV & 12 & $80 \pm 2$ & Active lifestyle \\
\hline $\mathrm{AD}$ & 12 & $80 \pm 2$ & $\begin{array}{l}\text { Late-onset possible/probable AD } \\
\text { No previous CVE or TBI }\end{array}$ \\
\hline NP & 12 & $78 \pm 2$ & $\begin{array}{l}\mathrm{PD}, \mathrm{MCI}, \mathrm{VaD}, \mathrm{CVE}, \mathrm{TBI} \\
\text { psychotic disorder, schizophrenia }\end{array}$ \\
\hline
\end{tabular}

SERUM ANALYSIS

Serum was separated by centrifugation from whole blood (10 min, 1,500 rpm) and stored at $-20^{\circ} \mathrm{C}$ until analysis. Glucose, total cholesterol and triglycerides were determined by standard colorimetric methods. Values were after classified as 'normal' or 'elevated' according to clinical standards to investigate the prevalence of the following common conditions that have been widely proposed as risk factors for Alzheimer's: hypertension, type 2 diabetes mellitus (hyperglycemia), hypercholesterolemia and hypertriglyceridemia.

\section{LYMPHOCYTE AND RNA ISOLATION}

To isolate lymphocytes from whole blood, samples collected in a tube containing EDTA were centrifuged $20 \mathrm{~min}$ at $850 \mathrm{xg}$ and $4^{\circ} \mathrm{C}$, the interphase containing white blood cells was diluted in an equal volume of PBS and layered over Lymphoprep (Nycomed Pharma) for a $20 \mathrm{~min}$ centrifugation at $400 \mathrm{x} \mathrm{g}$ and room temperature $\left(20-25^{\circ} \mathrm{C}\right)$. Total RNA was then isolated from the PBS washed pellet of lymphocytes using $1 \mathrm{~mL}$ Trizol Reagent (Invitrogen) according to manufacturer's instructions.
RT-PCR

Reverse transcription was performed using 2 $\mu \mathrm{g}$ of the isolated total RNA and M-MLV RT (Invitrogen), following manufacturer's instructions for both cDNA synthesis and PCR reactions. Endpoint PCR amplifications for tau, APP, NCT, BACE1 and glyceraldehyde-3-phosphate dehydrogenase (GAPDH) were carried out in 35 cycles of denaturation at $94^{\circ} \mathrm{C}$, annealing at $60^{\circ} \mathrm{C}$ and extension at $72^{\circ} \mathrm{C}$ for 30 seconds each using primers with the following sequences (Invitrogen):

$\begin{array}{lccc}\text { Gene } & \text { Primer } & \text { Primer sequence } & \begin{array}{c}\text { Product } \\ \text { size }\end{array} \\ \text { Tau } & \text { Forward } & \text { CAAAGCTCGCATGGTCAGTA } & 158 \mathrm{bp} \\ & \text { Reverse } & \text { AGGGTTGGATCAGAGGGTCT } & \\ \text { APP } & \text { Forward } & \text { CACAGAGAGAACCACCAGCA } & 178 \mathrm{bp} \\ & \text { Reverse } & \text { ACATCCGCCGTAAAAGATG } & \\ \text { NCT } & \text { Forward } & \text { CAAAGCACCTTCAGCATCAA } & 249 \mathrm{bp} \\ & \text { Reverse } & \text { GGTCACATCAGGTGCCTTT } & \\ \text { BACE1 } & \text { Forward } & \text { AGGGAGCATGATCATTGGAG } & 210 \mathrm{bp} \\ & \text { Reverse } & \text { AACACTTTCTTGGGCAAACG } & \\ \text { GAPDH } & \text { Forward } & \text { CGACCACTTTGTCAAGCTCA } & 228 \mathrm{bp} \\ & \text { Reverse } & \text { AGGGGTCTACATGGCAACTG } & \end{array}$

To test primers and PCR conditions were working properly, amplification reactions were carried out in the LNCaP human prostate adenocarcinoma cell line and a couple of samples of individuals with current inflammatory conditions by the time of collection (data not shown). The amplified products were visualized on $1 \%$ agarose gels stained with ethidium bromide and photographed with UV illumination for densitometric analysis of the bands to obtain relative expression.

\section{STATISTICAL ANALYSIS}

Comparisons between groups expression were performed by Student's t or Mann-Whitney's U tests, results are expressed as the mean \pm SEM. Raw values of all variables were used to investigate for correlations between APP, NCT and BACE1 expressions and for interactions between expression 
of these genes and blood pressure (comprising systolic pressure, diastolic pressure and pulse), glucose, total cholesterol and triglyceride levels. Correlation analyses for expression and the proposed risk factors were performed by Spearman's test. Differences were considered significant at $\mathrm{p}<0.05$ values.

\section{RESULTS}

\section{ANALYSIS OF RISK FACTORS OF INTEREST}

The most prevalent condition in our study population was hypercholesterolemia (40.28\%) followed by hypertriglyceridemia (38.89\%), hypertension $(33.33 \%)$ and hyperglycemia $(19.44 \%)$, in that order. We also determined the prevalence within each experimental group (Figure 1). A higher number of subjects presented with elevated levels of cholesterol in groups II and IV (58.3\%), groups III and II showed the highest prevalence of elevated triglycerides $(58.3 \%$ and $50.0 \%$, respectively). High blood pressure was presented by an equal number of individuals within each group $(33.3 \%$ each) while a bigger number of subjects in group IV presented with elevated levels of glucose $(33.3 \%)$.

\section{EXPRESSION ANALYSIS OF TAU, APP, NCT AND BACE1 IN LYMPHOCYTES}

Tau showed no expression in the study population under the conditions of this experiment but we were able to detect low expression levels of tau in the LNCaP cell line and the patients with inflammatory processes. We therefore ruled out tau expression for final data analysis of the study population.

APP and BACE1 did not significantly differ between groups. In contrast, NCT significantly differed in $\mathrm{AD}$ from group IV $(\mathrm{p}=0.037)$ and especially from group NP ( $\mathrm{p}=0.001)$ (Figure 2).

\section{ANALYSIS FOR INTERACTIONS}

Our results showed NCT to significantly correlate with APP $(p<0.001)$ and BACE1 $(p=0.01)$ while
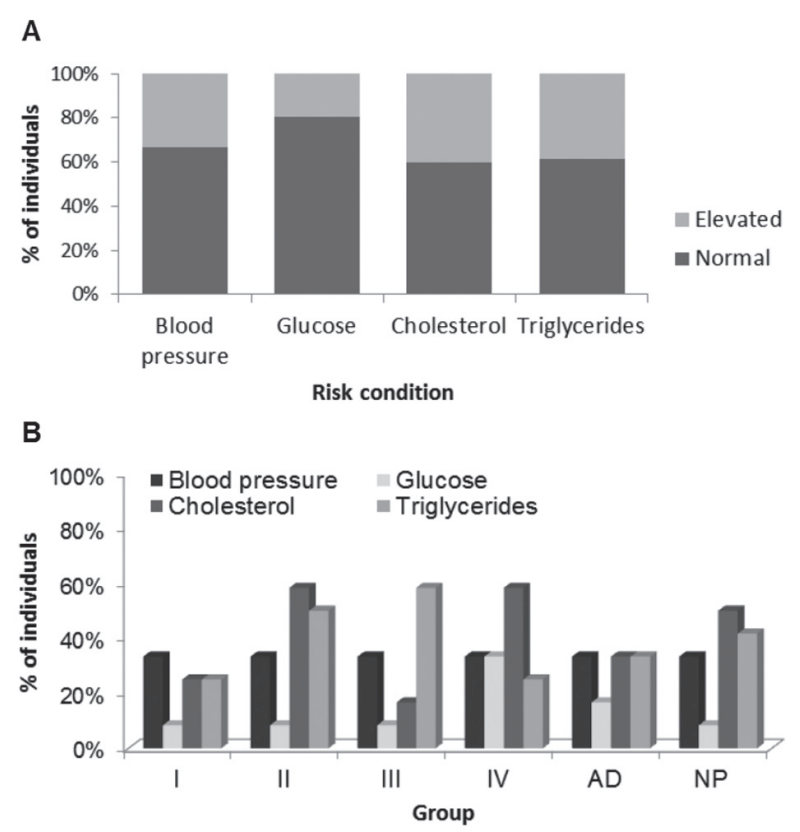

Figure 1 - Prevalence of the risk conditions of our interest. (A) Percentage of individuals with normal and elevated values of blood pressure, glucose, total cholesterol and triglycerides in our total population ( $\mathrm{N}=72)$. (B) Percentage of individuals within each experimental group $(n=12)$ presenting elevated levels for our risk conditions of interest.

them both do not correlate with each other; there is also evidence to suggest correlations between cholesterol, blood pressure and triglycerides levels with APP, NCT and BACE1 expressions as presented in Table II for the whole study population and Table III for each of the study groups. Only groups I and NP showed significant correlations, which differed between both groups.

\section{DISCUSSION}

We aimed to analyse the expression of molecules playing key roles in the pathophysiology of $\mathrm{AD}$ in lymphocytes, in order to investigate how they express throughout normal ageing and whether this might change result from disease, primarily AD. Nevertheless, other neurological/ neuropsychological conditions such as Parkinson's disease, cerebrovascular events, vascular dementia, mild cognitive impairment and psychiatric disorders (psychosis/schizophrenia) were grouped together 
A

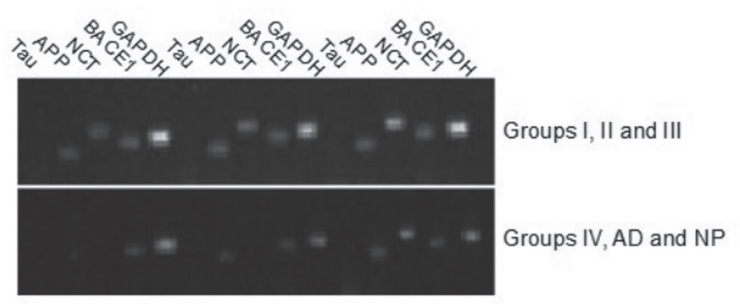

C

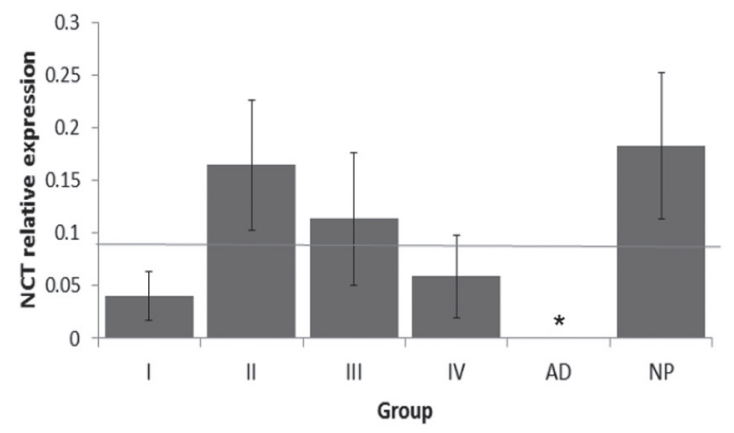

B

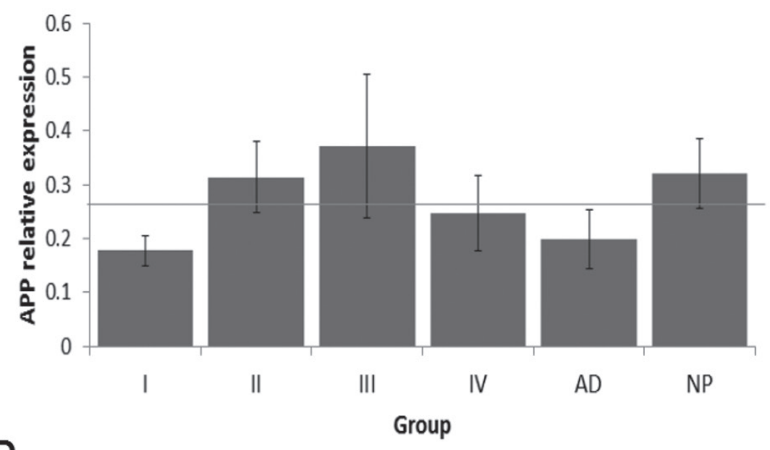

D

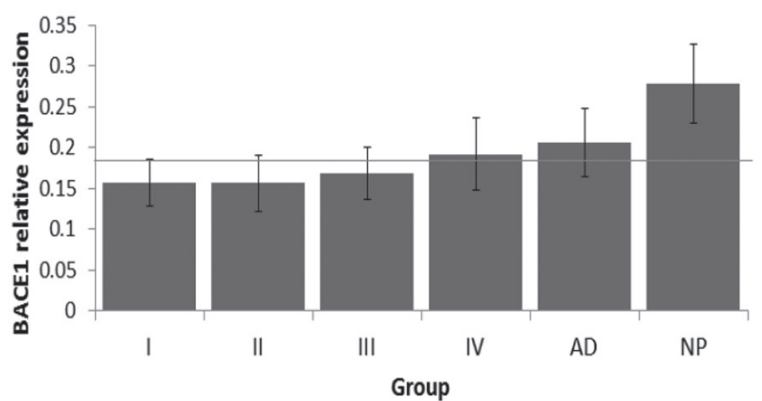

Figure 2 - Expression analysis. (A) Agarose gel of PCR products and relative expression of (B) APP, (C) nicastrin (NCT), and (D) $\beta$-secretase (BACE1). The thin gray line represents the overall mean. $(*)$ Only NCT in group AD showed a statistical significant difference at $\mathrm{p}<0.05$ when compared to groups IV and NP.

TABLE II

Correlation coefficients of the study population.

\begin{tabular}{cccc}
\hline Variables & APP & NCT & BACE1 \\
\hline APP & & $0.43 *$ & 0.21 \\
NCT & & & $0.30 *$ \\
Systolic pressure & -0.06 & 0.16 & 0.16 \\
Diastolic pressure & 0.04 & 0.01 & 0.04 \\
Pulse & $0.28 *$ & -0.15 & 0.00 \\
Glucose & 0.09 & -0.16 & 0.10 \\
Total cholesterol & 0.21 & $0.34 *$ & 0.13 \\
Triglycerides & -0.01 & 0.03 & -0.11 \\
\hline
\end{tabular}

* Significant correlation with $\mathrm{p}<0.05$.

and separate from $\mathrm{AD}$ to make sure the overall expression pattern presented by these disorders differed from that found for AD. As our focus is on $\mathrm{AD}$, it was not the aim of this study to analyse the expression patterns generated by each of the different neuropathologies included in group NP.
Endpoint RT-PCR was selected with exploratory purposes because of our interest in searching for features detectable with the most easily and widely available technologies.

Tau protein has been detected by immunocytochemistry in human peripheral lymphocytes (Kvetnoy et al. 2000). However, we were not able to detect tau expression by RT-PCR in our study population, apart from the very low expression levels detected in two young individuals presenting with a mild inflammatory process by the time of sample collection (data not shown). We believe this may suggest that chronic inflammatory processes occurring in the $\mathrm{AD}$ brain might not be enough to induce the expression of protein tau in lymphocytes in the same manner acute inflammatory conditions do.

The expression analysis of APP, NCT and BACE1 we performed in lymphocytes showed that neither of them changes significantly during 
TABLE III

Correlation coefficients of APP, NCT and BACE1 against values of blood pressure, glucose, cholesterol and triglycerides per group.

\begin{tabular}{|c|c|c|c|c|c|c|c|}
\hline Group & Gene & Syst P & Diast $\mathrm{P}$ & Pulse & Glucose & Cholesterol & Triglycerides \\
\hline \multirow{3}{*}{ I } & APP & 0.10 & 0.24 & 0.31 & -0.13 & -0.08 & -0.39 \\
\hline & $\mathrm{NCT}$ & 0.12 & -0.06 & -0.03 & 0.17 & 0.09 & -0.28 \\
\hline & BACE1 & 0.19 & 0.30 & 0.18 & 0.50 & $0.62 *$ & 0.18 \\
\hline \multirow{3}{*}{ II } & APP & 0.19 & 0.38 & 0.34 & 0.09 & 0.21 & 0.06 \\
\hline & NCT & 0.28 & 0.19 & -0.04 & 0.21 & 0.50 & 0.52 \\
\hline & BACE1 & 0.09 & 0.00 & -0.01 & 0.29 & 0.21 & 0.25 \\
\hline \multirow{3}{*}{ III } & APP & -0.33 & -0.41 & 0.43 & -0.05 & 0.13 & -0.33 \\
\hline & NCT & 0.04 & 0.04 & -0.33 & -0.08 & 0.18 & 0.02 \\
\hline & BACE1 & 0.25 & 0.49 & -0.27 & -0.00 & 0.26 & 0.02 \\
\hline \multirow{3}{*}{ IV } & APP & 0.08 & 0.37 & -0.44 & 0.09 & -0.01 & -0.48 \\
\hline & $\mathrm{NCT}$ & 0.16 & -0.32 & -0.28 & -0.22 & 0.25 & -0.34 \\
\hline & BACE1 & 0.34 & 0.15 & -0.40 & 0.43 & -0.25 & -0.39 \\
\hline \multirow{3}{*}{$\mathrm{AD}$} & APP & -0.38 & -0.08 & 0.49 & 0.45 & 0.40 & 0.41 \\
\hline & NCT & & & & & & \\
\hline & BACE1 & 0.21 & 0.28 & -0.00 & -0.42 & -0.18 & -0.49 \\
\hline \multirow{3}{*}{ NP } & APP & $0.58 *$ & 0.23 & 0.12 & 0.03 & 0.52 & $0.63 *$ \\
\hline & $\mathrm{NCT}$ & 0.56 & -0.11 & -0.36 & 0.03 & $0.63 *$ & -0.15 \\
\hline & BACE1 & 0.32 & 0.15 & 0.15 & 0.14 & -0.29 & -0.27 \\
\hline
\end{tabular}

* Significant correlation with $\mathrm{p}<0.05$.

normal ageing. Nevertheless, we observed a nonsignificant trend for APP and NCT to increase in midlife and for BACE1 to increase towards old age. While all individuals expressed variable levels of APP and BACE1, NCT expression could not be detected in some of the subjects despite their age or gender. In aged individuals suffering from neuropsychological conditions different from AD (NP group), NCT expression was relatively high and present in all samples; in contrast, NCT expression was not detected at all in the AD group. We should note that protein expression has not been yet analyzed and, as we are aware gene expression does not always reflect protein abundance, we attempt to do this next.

NCT also appears to correlate with APP and BACE1. Although the presence of nicastrin in the lymphocyte plasma membrane has been reported
(Peirce et al. 2004), there are no reports to our knowledge of gene expression in lymphocytes, especially from AD patients. Even with the limitations of this study, we believe these results can be promising and we seek to further investigate the potential of this feature as an $\mathrm{AD}$ biomarker in more depth and in a wider study population.

Regarding our investigation about common risk factors for $\mathrm{AD}$, we did not find an increased prevalence of elevated blood pressure, glucose, cholesterol and/or triglycerides in $\mathrm{AD}$ patients compared to the other groups; although we keep in mind that these patients might be under more strict medical control than cognitively healthy individuals. For the case of total cholesterol and triglycerides, lower lipid levels have been reported in serum from $\mathrm{AD}$ patients compared to healthy controls (Presecki et al. 2011). We found a positive 
correlation between APP expression and heart rate values, as well as for NCT and cholesterol, which we believe are due to a role of APP in stress responses mediated by catecholamines and association of NCT with cholesterol-rich lipid rafts. Our results suggest these clinical factors may interact with AD-related molecules not only in the brain but systemically to contribute to neuropathology, and may provide information that helps improve the diagnosis.

In conclusion, in this study we analysed the expression of tau, APP, nicastrin and BACE1 in peripheral blood lymphocytes through normal ageing and in $\mathrm{AD}$ /neuropsychological patients. Our results indicate there is no significant change in expression through ageing even if a trend might be observed. As our second interest resided in comparing the aged group taken as control against Alzheimer's and other neuropsychological disorders such as Parkinson's, cerebrovascular conditions and psychiatric syndromes, we found herein that APP and BACE1 expression remains without significant change, while as for nicastrin there is a lack of expression in lymphocytes from all AD patients. This feature is shared by some cognitively normal subjects but as we investigated for common variables amongst them we were not able to find any. Furthermore, neuropsychiatric patients not suffering from $A D$ expressed relatively high levels of nicastrin. We have found these results to be of interest to perform more in depth analyses in a wider population and to include protein expression and more accurate quantitative technologies.

Although we reported no data for tau due to a lack of expression in all the subjects suitable to our study criteria, our results suggest tau expression might be induced in lymphocytes by acute inflammatory processes but not by the neuroinflammation in AD.

Patients suffering from possible or probable AD showed no higher prevalence of medical conditions such as hypertension, type 2 diabetes mellitus, hypercholesterolemia and/or hypertriglyceridemia but this does not rule out the possibility of them being linked to an increased risk to develop the disease. However, we did find a correlation between total cholesterol and blood pressure values with NCT and APP expression, respectively, which corroborates that interactions between expression and nutritional/environmental/lifestyle factors are established in the periphery and could be linked to a variety of age-related diseases.

To our knowledge, our observations on nicastrin expression in lymphocytes from healthy subjects through ageing and $\mathrm{AD}$ patients have not been previously reported. Even when strong conclusions may not be generated by this exploratory study, we suggest that the potential of nicastrin as a biomarker to differentiate $\mathrm{AD}$ from other neuropsychiatric disorders in peripheral lymphocytes (and, probably, other blood cells) might be promising and therefore should be further investigated in more depth.

\section{ACKNOWLEDGMENTS}

The authors would like to thank Abraham SotoCid for his help at the clinical laboratory and doctors Rocío Coutiño and Enrique Juárez at the Institutes of Public Health and Health Sciences, who kindly allowed the occasional use of their facilities. Also to the Consejo Nacional de Ciencia y Tecnología (CONACYT, Mexico) for the doctoral scholarship number 223277 in biomedical sciences granted to M.H.R.

\section{RESUMO}

Embora a doença de Alzheimer seja um distúrbio do cérebro, uma série de alterações periféricas têm sido encontradas nesses pacientes; no entanto, pouco se sabe sobre como os genes envolvidos na fisiopatologia se expressam nas células periféricas, tais como em linfócitos durante o envelhecimento normal em comparação com o neuropatológico. Analisamos por RT-PCR a expressão dos genes de tau, da proteína precursora do amilóide, de nicastrin e da enzima de clivagem do sítio $\beta$ da APP, em linfócitos de um pequeno grupo de pacientes com início 
tardio da Doença de Alzheimer, de um grupo de pacientes idosos que sofrem de doenças neuropsicológicas diferentes de Alzheimer, e de um grupo de indivíduos cognitivamente saudáveis, divididos em quatro grupos por idade. Também foram investigadas as correlações entre a expressão dos genes e os níveis de pressão arterial, glicose, colesterol total e triglicérides, como fatores de risco para doença de Alzheimer. Os resultados mostram a ausência de expressão de tau em linfócitos, a ausência de detecção da expressão do gene de nicastrina em pacientes com Alzheimer, e a correlação entre as condições médicas estudadas e a expressão gênica nos linfócitos. Acreditamos que a expressão de nicastrin em linfócitos deve ser considerada de interesse para análises em uma população mais ampla, para investigar se ela pode representar um potencial biomarcador para diferenciar a doença de Alzheimer de outros distúrbios neuropsicológicos.

Palavras-chave: doença de Alzheimer, APP, BACE1, nicastrin, envelhecimento normal, fatores de risco.

\section{REFERENCES}

Ballatore C, LeE VM And Trojanowski JQ. 2007. Taumediated neurodegeneration in Alzheimer's disease and related disorders. Nat Rev Neurosci 8: 663-672.

BRITSHGI M AND WYSS-CORAY T. 2007. Systemic and acquired immune responses in Alzheimer's disease. Int Rev Neurobiol 82: 205-233.

Cheng D, Noble J, Tang MX, Schupf N, Mayeux R And LUCHSINGER JA. 2011. Type 2 diabetes and late-onset Alzheimer's disease. Dement Geriatr Cogn Disord 31: 424-430.

De LeOn MJ, Mosconi L, BLENNOW K, DESANTI S, ZINKOWSKI R AND MEHTA PD. 2007. Imageing and CSF studies in the preclinical diagnosis of Alzheimer's disease. Ann N Y Acad Sci 1097: 115-145.

Di PAOLO G AND KIM TW. 2011. Linking lipids to Alzheimer's disease: cholesterol and beyond. Nat Rev Neurosci 12: 284-296.

GladKeVICH A, KAUfFMAN HF AND KORF J. 2004. Lymphocytes as a neural probe: potential for studying psychiatric disorders. Prog Neuropsychopharmacola Biol Psychiatry 28: 559-576.

IRIZARRY MC. 2004. Biomarkers of Alzheimer Disease in Plasma. J Am So Exp NeuroTherapeutics 1: 226-234.

JimÉnEZ-JimÉnEZ FJ, ALONSO-NAVARRO H, AYUSO-PERALTA L AND JABBOUR-WADIH T. 2006. Oxidative stress and Alzheimer's disease (article in Spanish). Rev Neurol 42: 419-427.
JORM AF. 1990. The epidemiology of Alzheimer's disease and related disorders. London: Chapman \& Hall, $234 \mathrm{p}$.

KÁlmán J, KitAJKa K, PÁKÁSKi M, ZVARA Á, JuHÁSZ A AND VINCZE G. 2005. Gene expression profile analysis of lymphocytes from Alzheimer's patients. Psychiatr Genet 15: 1-6.

KVETNOY IM, HERNÁNDEZ-YAgo J, KVETnAIA TV, KHAVINSON VK, MALININ VV AND YARILIN AA. 2000. Tau-protein expression in human blood lymphocytes: a promising marker and suitable sample for life-time diagnosis of Alzheimer's disease. Neuro Endocrinol Lett 21: 313-318.

LANE RM AND FARLOW MR. 2005. Lipid homeostasis and apolipoprotein $\mathrm{E}$ in the development and progression of Alzheimer's disease. J Lipid Res 46: 949-968.

Peirce MJ, Wait R, Begum S, Saklatvala J And Cope AP. 2004. Expression profiling of lymphocyte plasma membrane proteins. Mol Cell Proteomics 3: 56-65.

Presecki P, MÜCK-Seler D, Mimica N, Pivac N, Mustapid M AND STIPCEVIC T. 2011. Serum lipid levels in patients with Alzheimer's disease. Coll Antropol 35: 115-120.

RAY S, Britschgi M, Herbert C, TAKEDA-UChIMURA Y, BOXER A AND BLENNOW K. 2007. Classification and prediction of clinical Alzheimer's diagnosis based on plasma signaling proteins. Nat Med 13: 1359-1362.

RaZAY G, VReugdenhil A And Wilcock G. 2007. The metabolic syndrome and Alzheimer disease. Arch Neurol 64: 93-96.

SELKOE DJ. 2001. Alzheimer's disease: genes, proteins and therapy. Physiol Rev 81: 741-766.

SUZUKI T, ARAKI Y, YAMAMOTO T AND NAKAYA T. 2006 Trafficking of Alzheimer's disease-related membrane proteins and its participation in disease pathogenesis. $\mathrm{J}$ Biochem 139: 949-955.

TUPPO EE AND ARIAS HR. 2005. The role of inflammation in Alzheimer's disease. Int J Biochem Cell Biol 37: 289-305.

Uemura K, Kuzuya A and Shimohama S. 2004. Protein trafficking and Alzheimer's disease. Curr Alzheimer Res 1: 1-10.

VASSAR R AND KANDALEPAS PC. 2011. The $\beta$-secretase enzyme BACE1 as a therapeutic target for Alzheimer's disease. Alzheimers Res Ther 3: 20.

YANG M, CAI F, PAN Q, LONG ZG, XIA JH AND XIA K. 2009. Transcriptional regulation of the Alzheimer's diseaserelated gene, nicastrin. Progress in Biochemistry and Biophysics 36: 994-1002. 